\title{
The anticancer agent PB-100, selectively active on malignant cells, inhibits multiplication of sixteen malignant cell lines, even multidrug resistant
}

\author{
Mirko Beljanski ${ }^{+}$
}

\begin{abstract}
The plant-derived anticancer agent PB-100 selectively destroys cancer cells, even when multidrug resistant; yet, it does not inhibit normal (non-malignant) cell multiplication. Testing of PB-100 on sixteen malignant cell lines, several multidrug resistant, as well as on five normal cell lines, confirmed our previous results. Flavopereirine and dihydroflavopereirine, the active principles of PB-100, were chemically synthesized and displayed the same selectivity for tumor cells as the purified plant extract, being active at even lower concentrations.
\end{abstract}

\section{INTRODUCTION}

From its very beginnings almost half a century ago, cancer chemotherapy has faced dramatic problems. Lack of selectivity of conventional anticancer agents, which damage not only malignant but also normal cells, in particular blood cells, has made the scientific community aware of the need for more specifically selective drugs (Pisha et al., 1995). Another drawback, which arose just after cancer chemotherapy was started, was the appearance of drug-resistant cancer cells (Moscow and Cowan, 1988; Israel, 1989; Gottesman, 1993). Several resistance mechanisms have been identified, which researchers are actively trying to overcome; however, few satisfactory solutions have been proposed; moreover, trying to suppress or bypass drug resistance generally means adding a new drug to the anticancer regimen, thus increasing the risk of adverse side effects.

We demonstrated experimentally that our anticancer agent PB-100 selectively destroys cancer cells, but has no effect on their normal (non-malignant) counterparts (Beljanski and Bugiel, 1978; Beljanski, 1979, 1983; Beljanski and Beljanski, 1982, 1984, 1986). Moreover, it has proven to be active, in vitro, on the highly malignant $\mathrm{U} 251$ glioblastoma cells, which are both radio- and BCNU-resistant (Beljanski et al., 1993; Beljanski and Crochet, 1994).

We have now tested the activity of PB-100 in vitro on sixteen different malignant cell lines, some of which are resistant to conventional therapy, as well as on five normal cell lines. Results presented here confirm previous ones, by showing destruction of over $90 \%$ of cancer cells (74 to $98 \%$, depending on cell line) using maximal product concentrations of $100 \mu \mathrm{g} / \mathrm{ml}$; normal cells remained unaffected.

PB-100 is the plant-derived alkaloid flavopereirine, utilized in the form of a purified plant extract containing both flavopereirine and dihydroflavopereirine. Pure syn- thetic flavopereirine and dihydroflavopereirine proved to be more active on U251 cancer cells than the natural product; like the latter, these compounds spared normal astrocytes.

\section{MATERIAL AND METHODS}

Chemicals

Trypsin, RPMI 1640 culture medium, fetal calf serum, glutamine: Gibco, Grand Island, NY, USA. Anticancer agents: PB-100 was purified in our laboratory and checked for purity using HPLC, UV absorbance spectra and thin layer chromatography.

Pure, synthetic flavopereirine and dihydroflavopereirine were a gift from Dr. A. Fürstner, Max-Planck Institute, Muhlheim, Germany.

\section{Cell lines and culture techniques}

Brain cell lines: U251 human 1,3-Bis (2-chloroethyl)1 nitrosourea (BCNU)- and radiation-resistant glioblastoma; CCF-STTG-l and SW 1088 human astrocytomas; C6 rat glial tumor; CRL $1656 \mathrm{Mpf}$ normal astrocytes.

Ovarian cell lines: ES2 human carcinoma, exhibiting low to moderate multidrug resistance (MDR) (doxorubicin, cisplatin, carmustine, etoposide, cyanomorpholine doxorubicin...); SW 626, human adenocarcinoma.

Breast cancer cell lines: MCF-7 and ZR-75-1 human carcinoma.

Prostate cell line: cisplatin-, adriamycin- and etoposide-resistant PC3 human carcinoma.

Colon cell lines: LoVo human adenocarcinoma; chemoresistant $\mathrm{CaCo}-2$ human adenocarcinoma; $\mathrm{CCD}-18$ Co human normal colon cells.

Thyroid cell line: TT human medullary carcinoma. Pancreatic cell line: MIA PaCa-2 human carcinoma. 
Hepatic cell lines: Sk-Hep 1 human adenocarcinoma; clone 9 normal rat liver cells.

Kidney cell lines: A 498 human carcinoma; NRK49F normal rat kidney fibroblasts.

Skin cell lines: G-361 human malignant melanoma; CCD-974Sk normal human fibroblasts.

All cell lines were obtained from ATCC, Rockville, MD, USA, except U251, obtained from SCC, Uppsala, Sweden.

\section{Cell culture}

After checking for the absence of mycoplasms and bacteria, cells were grown at $37^{\circ} \mathrm{C}$ as monolayer confluent cells in RPMI 1640 medium supplemented with $10 \%$ calf serum. To avoid cell membrane sensitization, no antibiotics were used. Stock cultures were duplicated weekly after addition of trypsin (+0.005\% EDTA), to disperse cells for inoculation. All cell lines were cultured in several 6well tissue culture plates $\left(9.8 \mathrm{~cm}^{2}\right.$ wells $)$, starting from a $4 \times 10^{4}$-inoculum, and grown for $48 \mathrm{~h}$ (doubling time: 20 $24 \mathrm{~h}$ ), prior to assays.

\section{Cell growth inhibition}

The antiproliferative activity of PB-100 was determined following addition of increasing concentrations of the agent to culture media containing the cell inoculum. Dead cells were found in suspension; remaining viable cells were trypsinized and counted with a Coulter counter.

\section{RESULTS}

\section{Assays using the plant-derived purified extract}

After each cell line had been grown in vitro for $48 \mathrm{~h}$ either in the absence or in the presence of concentrations ranging from 10 to $100 \mu \mathrm{g} / \mathrm{ml}$ of $\mathrm{PB}-100$, the number of surviving cells was estimated as the percentage of cells growing in the absence of PB-100 (100\%). Anticancer agent activity was dose dependent (Beljanski et al., 1993); $100 \mu \mathrm{g} / \mathrm{ml}$ was found to be the most active concentration (Table I). Typically, from 80 to $98 \%$ of malignant cells, depending on the cell line, were killed by this concentration of PB-100, which left over $95 \%$ of normal cells viable. Multiplication of normal astrocytes was actually increased, perhaps due to the presence of ATPase in the culture medium (Beljanski et al., 1993).

Table I indicates that PB-100 is as active on drugresistant tumor lines as on other malignant lines. Examples found in Table I are: U251 BCNU- and radiation-resistant human glioblastoma cells, ES2 multidrug-resistant human ovarian carcinoma cells, and PC-3 multidrug-resistant human prostate carcinoma cells. According to our 20 years of experience, PB-100 itself never induced cancer cell resistance either in vitro or in vivo.
Table I - Effect of PB100 on multiplication of cancer and normal cell lines from various organs.

\begin{tabular}{lclc|}
\hline \multicolumn{2}{|c|}{ Cancer cell lines } & \multicolumn{2}{c|}{ Normal cell lines } \\
\hline Brain & & & \\
U 251 & O.36 \pm 3.2 & CRL 1656 & $162 \pm 5.64$ \\
CCF-STTG-1 & $2.29 \pm 5.69$ & & \\
SW 1088 & $2.18 \pm 0.51$ & & \\
C6 & $5.96 \pm 3.71$ & & \\
Colon & & & \\
LoVo & $4.65 \pm 1.14$ & CCD-18Co & $102.14 \pm 1.17$ \\
CaCo-2 & $4.74 \pm 5.02$ & & \\
Liver & & & \\
Sk-Hep 1 & $5.52 \pm 3.13$ & Clone 9 & \\
Kidney & & & \\
A 498 & $4.34 \pm 0.56$ & NRK-49F & \\
Skin & & & \\
G-361 & $3.39 \pm 1.23$ & CCD-974Sk & $100.65 \pm 2.87$ \\
Ovary & & & \\
ES 2 & $2.14 \pm 1.03$ & & \\
SW 626 & $4.43 \pm 2.16$ & & \\
Breast & & & \\
ZR-75-1 & $16.22 \pm 3.02$ & & \\
MCF-7 & $10.34 \pm 1.59$ & & \\
Pancreas & & & \\
MIA PaCa2 & $2.59 \pm 5.23$ & & \\
Prostate thyroid & & & \\
PC3 & & & \\
TT & & & \\
\hline
\end{tabular}

Number of remaining cells (\%) after a 48-h incubation in the presence of PB100 $(100 \mu \mathrm{g} / \mathrm{ml})$.

\section{Assays using pure flavopereirine and dihydroflavopereirine}

Using U251 BCNU-resistant glioblastoma cells and normal CRL 1656 astrocytes as controls, we compared the effect of pure synthetic flavopereirine or dihydroflavopereirine, the active components of PB-100, with that of PB-100 purified in our laboratory from a plant extract. It may be seen from Figures 1 and 2 that the same extent of cancer cell destruction obtained using the optimal 100 $\mu \mathrm{g} / \mathrm{ml}$ concentration of purified plant extract was reached using $50 \mu \mathrm{g} / \mathrm{ml}$ of either synthetic dihydroflavopereirine or synthetic flavopereirine. At this concentration, flavopereirine slightly reduced normal cell multiplication, while dihydroflavopereirine did not affect it at all.

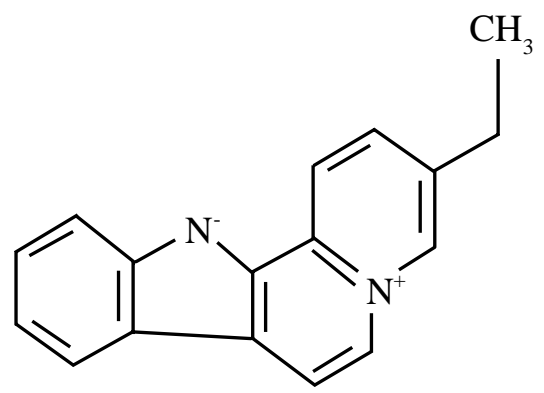

Flavopereirine 


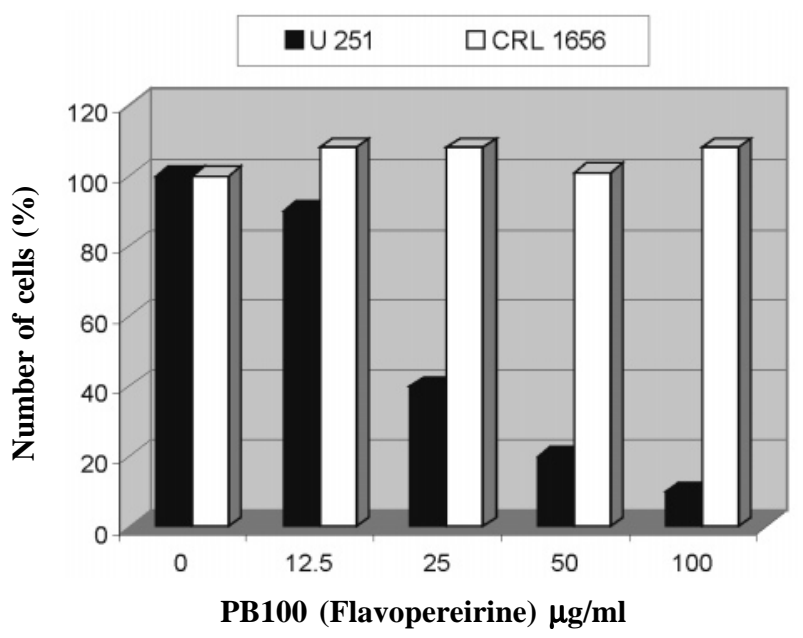

Figure 1 - Effect of increasing concentrations of plant-derived flavopereirine (PB100) on human glioblastoma (U 251) and normal astrocyte (CRL 1656) cell lines.
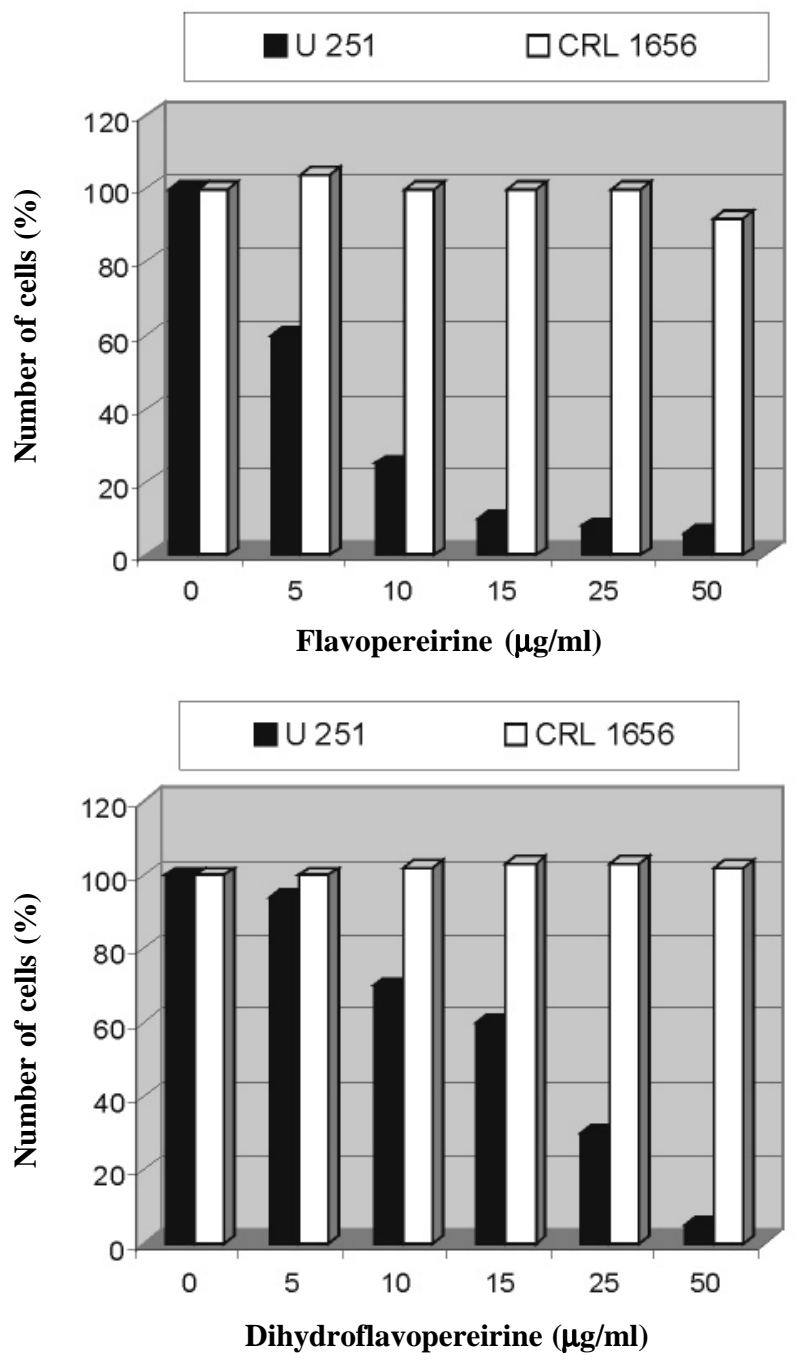

Figure 2 - Effect of chemically synthesized flavopereirine and dihydroflavopereirine on the multiplication of human glioblastoma (U 251) and normal astrocyte (CRL 1656) cell lines.

\section{DISCUSSION}

Currently applied conventional chemotherapy not only lacks selectivity and does not spare normal (non-malignant) cells when killing cancer cells, it also too often induces resistance of tumor cells to antineoplastic agents, generally in the form of "multidrug resistance" to structurally unrelated compounds (Beljanski and Crochet, 1994; Preisler, 1995; Bosch and Croop, 1996).

Results reported here indicate that PB-100 selectively destroys cancer cells, while having no effect on normal cells, and that drug and/or radiation resistance of the cell lines used does not impair PB-100 activity.

Selectivity of our anticancer agent is linked to the characteristic property of cancer DNA, which we demonstrated experimentally many years ago: malignant DNA is a relaxed, destabilized molecule, because many of its $\mathrm{H}$ bonds have been broken; along these abnormally and permanently separated strand areas, normally unused initiation sites have become available to replication and transcription enzymes. Many other endogenous and exogenous molecules can also easily gain access to the "open" cancer DNA chains, in contrast to strands of the normal DNA molecule, which only separate locally and temporarily for gene replication and expression (Beljanski and Beljanski, 1982; Beljanski, 1983). We showed that several plant-derived molecules, and specifically PB-100, are able to restabilize cancer DNA by bringing its separated strands back together (Beljanski and Beljanski, 1982; Beljanski, 1990; Beljanski et al., 1993; Beljanski and Crochet, 1996). We also demonstrated that PB-100 rapidly concentrates in the tumor cell nucleus and nucleoli, but does not even enter normal cells. PB-100 preferentially binds to purine-rich nucleic acid stretches. This may explain its nuclear and nucleolar concentration in tumor cells (Beljanski and Crochet, 1995).

Prevention of its entry into normal cells is as yet unexplained, though it is well known that membrane properties of cancer and normal cells differ. Could iron concentration be higher at the surface of normal cells and thus bind PB-100 before it enters? To account for cancer cell resistance to antineoplastic agents, a variety of mechanisms have been identified (Israel, 1990; Belpomme, 1991; Bouffard et al., 1996). The efflux pump system, which prevents accumulation of cytotoxic drugs by actively pumping them out of resistant cells, involves, singly or together, the products of several genes encoding ATP-binding glycoproteins: multidrug-resistance gene 1 ( $m d r l)$, expressed as the membrane-associated P-glycoprotein pump (Moscow and Cowan, 1988; Choi et al., 1988; Israel, 1989; Skovsgaard, 1989; Nooter and Herweijer, 1991; Serra et al., 1993; Bosch and Croop, 1996; Bouffard et al., 1996; Gottesman et al., 1996); mrp, expressed as the "multidrug resistance-associated protein" (Morgan, 1993; Nooter et al., 1995; Flens et al., 1996; Bouffard et al., 1996), and the more recently identified lrp, expressed as 
the "lung-resistance-related protein" (LRP) in a non-small cell lung carcinoma line (Bouffard et al., 1996; Izquierdo et al., 1996). Other important resistance pathways include changes in the regulation of drug-metabolizing enzymes such as glutathione-S-transferase (Townsend and Cowan, 1989; Caffrey and Frenkel, 1994; Preisler, 1995) and altered topoisomerase II activity (Moscow and Cowan, 1988; Glisson, 1989; Preisler, 1995). Mutations of the $p-53$ gene and overexpression of the $b c 1-2$ gene have been associated with "regrowth resistance" (rapid cancer cell proliferation between courses of cytotoxic therapy) and to inhibition of the normal apoptotic response to severe DNA damage (Preisler, 1995).

However, not only are P-glycoproteins, like glutathione -S-transferase, and presumably also MRP and LRP, involved in normal cell detoxication processes (Nooter et al., 1995; Flens et al., 1996; Izquierdo et al., 1996), but these are also present in many different normal tissues and organs, such as adrenals, the gravid uterus, kidney, liver, colon or capillary endothelium in the brain, where their precise physiological functions (some of which seem to be linked to secretion) have not been fully ascertained (Tsuruo and Tomida, 1995).

Although a difficult process, MDR reversal must not endanger these physiological functions. Advances have been mostly achieved in vitro: they include the use of the calcium channel inhibitor verapamil, of the immunosuppressive drug cyclosporin $\mathrm{A}$, and of quinoline derivatives such as the antimicrobial agent difloxacin, all reported to compete with the binding of antineoplastic drug for the active P-glycoprotein pump site. Yet, clinical use of these compounds is limited by their toxicities (Lehnert, 1993; Huet et al., 1993; Tsuruo and Tomida, 1995; Dhainaut et al., 1996; Bouffard et al., 1996). Monoclonal antibodies have also proven to be able to reverse MDR and, in addition, may contribute to the immune response (Tsuruo and Tomida, 1995). Oligonucleotide modulation has also been proposed for MDR reversal, through the use of antisense oligodeoxynucleotides and ribozymes, but proper delivery systems and targeting have yet to be developed (Bouffard et al., 1996).

Experiments described in the present paper confirm, as reported previously (Beljanski et al., 1993), that PB100 activity is unaffected by tumor cell drug resistance. In resistant human cell lines of three different origins, namely, glioblastoma, ovarian and prostate carcinomas, the anticancer agent displays the same activity shown in other malignant cell lines. We do not know which resistance mechanisms are present in the malignant cells tested. However, both in the course of our numerous in vitro experiments and in the hands of physicians and veterinarians who have been giving their patients PB-100 for over ten years, we have never witnessed or been informed about any PB-100-induced tumor cell resistance.

PB-100 is a purified, well-defined extract of $\mathrm{Pao}$ pereira (Apocynaceae). Its active principles are flavo- pereirine and dihydroflavopereirine. We have now tested the activity of chemically synthesized flavopereirine and dihydroflavopereirine on radiation- and BCNU-resistant U251 glioblastoma cells and CRL 1656 astrocytes used as normal controls, and shown that these molecules display the same marked and fully specific anticancer activity of the plant extract, confirming the hypothesis that these two alkaloids are responsible for PB-100 activity. As expected, the synthetic molecules are individually more active than the plant extract. Flavopereirine exhibited the strongest effect on tumor cells; it differs from its dihydro derivative by having two charged nitrogen atoms which enable it to behave as a dipolar zwitterion, a condition which apparently facilitates its activity in comparison to that of its dihydro form, at intracellular conditions.

Because low doses of conventional chemotherapeutic agents or of radiation contribute to $\mathrm{H}$-bond cleavage, thus facilitating PB-100 binding to cancer DNA (Beljanski and Beljanski, 1986), this anticancer agent, used in synergy with classic treatments, has led to improved results. Because of its selectivity for tumor cells, absence of adverse effects on normal cells, and indifference to malignant cell drug resistance, PB-100 should find a place in anticancer strategy. Hopefully, its chemically synthesized active principles will then also become of use.

\section{ACKNOWLEDGMENTS}

We thank Sylvie Crochet for technical assistance, and Claudy Nordau for reading the manuscript.

\section{RESUMO}

O agente anticancerígeno de origem vegetal PB-100 destrói seletivamente as células cancerosas, mesmo quando elas são resistentes a múltiplas drogas; no entanto, ele não inibe a multiplicação de células normais (não malignas). O teste do PB-100 em 16 linhagens de células malignas, assim como em 5 linhagens de células normais, confirmou nosso resultados prévios. Flavopereirine e dihidroflavopereirine, os princípios ativos do PB-100, foram sintetizados quimicamente e mostraram a mesma seletividade para as células tumorais que o extrato purificado da planta, sendo ativos em concentrações ainda menores.

\section{REFERENCES}

Beljanski, M. (1979). Oncotest: a DNA assay system for the screeening of carcinogenic substances. Int. Res. Commun. Syst. 7: 476.

Beljanski, M. (1983). The regulation of DNA replication and transcription. The role of trigger molecules in normal and malignant gene expression. In: Experimental Biology and Medicine (Wolsky, A., ed.). Vol. 8. Karger, Basel.

Beljanski, M. (1990). Cancer therapy: a new approach. Dtsch. Z. Onkol. 22: $145-152$

Beljanski, M. and Beljanski, M.S. (1982). Selective inhibition of in vitro synthesis of cancer DNA by alkaloids of beta-carboline class. Expl. Cell Biol. 50: 79-87.

Beljanski, M. and Beljanski, M.S. (1984). Three alkaloids as selective destroyers of the proliferative capacity of cancer cells. Inst. Res. Commun. Syst. Med. Sci. 12: 587-588. 
Beljanski, M. and Beljanski, M.S. (1986). Three alkaloids as selective destroyers of cancer cells in mice. Synergy with classic anticancer drugs. Oncology 43: 198-203.

Beljanski, M. and Bugiel, J. (1978). Brevets d'Invention (patents). Nos. 7807155 and 7830663 , France.

Beljanski, M. and Crochet, S. (1994). The selective anticancer agent PB-100 inhibits interleukin-6 induced enhancement of glioblastoma cell proliferation in vitro. Int. J. Oncol. 5: 873-879.

Beljanski, M. and Crochet, S. (1995). The anticancer agent PB-100 concentrates in the nucleus and nucleoli of human glioblastoma cells, but does not enter normal astrocytes. Int. J. Oncol. 7: 85-87.

Beljanski, M. and Crochet, S. (1996). Mitogenic effect of several interleukins, neuromediators and hormones on human glioblastoma cells, and its inhibition by the selective anticancer agent PB-100. Dtsch. Z. Onkol. 28: 14-22.

Beljanski, M., Crochet, S. and Beljanski, M.S. (1993). PB-100: a potent and selective inhibitor of human BCNU resistant glioblastoma cell multiplication. Anticancer Res. 13: 2301-2308.

Belpomme, D. (1991). Diversité des mécanismes de résistance aux chimiothérapies anticancéreuses. Méd./Sci. 7: 465-472.

Bosch, I. and Croop, J. (1996). P-glycoprotein multidrug resistance and cancer. Biochim. Biophys. Acta 1288: F37-F54.

Bouffard, D.Y., Ohkawa, T., Irie, A., Suzuki, T., Curcio, L.D., Holm, P.S., Sassani, A. and Scanlon, K.J. (1996). Oligonucleotide modulation of multidrug resistance. Eur. J. Cancer 32A: 1010-1018.

Caffrey, P.B. and Frenkel, G.D. (1994). The development of drug resistance by tumor cells in vitro is accompanied by the development of sensitivity to selenite. Cancer Lett. 81: 59-65.

Choi, K., Chen, C., Kriegler, M. and Roninson, I.B. (1988). An altered pattern of cross-resistance in multidrug-resistant human cells results from spontaneous mutations in the MDR-1 (P-glycoprotein) gene. Cell 53: 520-529.

Dhainaut, A., Régnier, G., Tizot, A.,Pierre, A., Léonce, S., Guilbaud, N., KrausBerthier, L. and Atassi, G. (1996). New purines and purine analogs as modulators of multidrug resistance. J. Med. Chem. 39: 4099-4108.

Flens, M.J., Zaman, G.J.R., van der Valk, P., Izquierdo, M.A., Schroeijers, A.B., Scheffer, G.L., van der Groep, P., de Haas, M., Meijer, C.J.L.M. and Scheper, R.J. (1996). Tissue distribution of the multidrug resistance protein. Am. J. Pathol. 148: 1237-1247.

Glisson, B.S. (1989). Multidrug resistance mediated through alterations in topoisomerase II. Cancer Bull. 41: 37-40.

Gottesman, M.M. (1993). How cancer cells evade chemotherapy: sixteenth Richard and Hinda Rosenthal Foundation award lecture. Cancer Res. 53: 747-754.

Gottesman, M.M., Pastan, I. and Ambudkar, S.V. (1996). P-glycoprotein and multidrug resistance. Curr. Opin. Genet. Dev. 6: 610-617.
Huet, S., Chapey, C. and Robert, J. (1993). Reversal of multidrug resistance by a new lipophilic cationic molecule, S9788. Comparison with 11 other MDR-modulating agents in a model of doxorubicin-resistant rat glioblastoma cells. Eur. J. Cancer 29A: 1377-1383.

Israel, L. (1989). Les résistances causes d'échecs des chimiothérapies anticancéreuses. Path. Biol. 37: 125-127.

Israel, L. (1990). Pourquoi des résistances? Cancérologie 97: 43-46.

Izquierdo, M.A., Scheffer, G.L., Flens, M.J., Giaccone, G., Broxterman, H.J., Meijer, C.J.L.M., van der Valk, P. and Scheper, R.J. (1996). Broad distribution of the multidrug-resistance related vault lung resistance protein in normal human tissues and tumors. Am. J. Pathol. 148: 877-887.

Lehnert, M. (1993). Reversal of P-glycoprotein-associated multidrug resistance. Eur. J. Cancer 29A: 636-638.

Morgan, P.P. (1993). New hope for overcoming acquired drug resistance. Can. Med. Assoc. J. 148: 1713-1716.

Moscow, J.A. and Cowan, K.H. (1988). Multidrug resistance. J. Nat. Cancer Inst. 80: 14-20.

Nooter, K. and Herweijer, H. (1991). Multidrug resistance (mdr) genes in human cancer. Br. J. Cancer 63: 663-669.

Nooter, K., Westerman, A.M., Flens, M.J., Zaman, G.J.R., Scheper, R.J., van Wingerden, K.E., Burger, H., Oostrum, R., Boersma, T., Sonneveld, P., Gratama, J.W., Kok, T., Eggermont, A.M.M., Bosman, F.T. and Stoter, G. (1995). Expression of the multidrug resistance-associated protein (MRP) gene in human cancers. Clin. Cancer Res. 1: 1301-1310.

Pisha, E., Chai, H., Lee, I.-S., Chagwedera, T.E., Farnsworth, N.R., Cordell, G.A., Beecher, C.W.W., Fong, H.H.S., Kinghorn, A.D., Brown, D.M., Wani, M.C., Wall, M.E., Hieken, T.J., Das Gupta, T.K. and Pezzuto, J.M. (1995). Discovery of betulinic acid as a selective inhibitor of human melanoma that functions by induction of apoptosis. Nat. Med. 1: 1046-1051.

Preisler, H.D. (1995). Multidrug resistance is more than MDRl activity. Leuk Res. 19: 429-431.

Serra, M., Scotlandi, K., Manara, M.C., Maurici, D., Lollini, P.-L., de Giovanni, C., Toffoli, G. and Baldini, N. (1993). Establishment and characterization of multidrug-resistant human osteosarcoma cell lines. Anticancer Res. 13: 323-330.

Skovsgaard, T. (1989). Drug transport in multidrug-resistant tumor cells. A revision of the pump hypothesis. Anticancer Drugs (Tapiero, H., Robert, J. and Lampidis, T.J, eds.). Colloque INSERM/John Libbey Eurotext Ltd., France, pp. 233-244.

Townsend, A.J. and Cowan, K.H. (1989). Glutathione S-transferases and antineoplastic drug resistance. Cancer Bull. 41: 31-36.

Tsuruo, T. and Tomida, A. (1995). Multidrug resistance. Anticancer Drugs 6: 213-218.

(Received September 1, 1999) 
